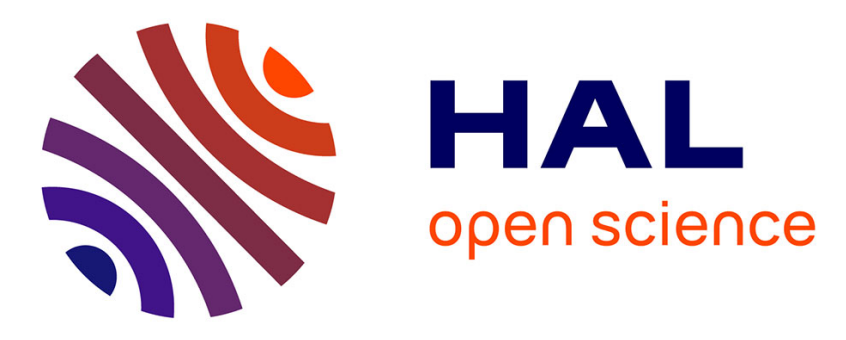

\title{
Partial migration in inexperienced pied avocets Recurvirostra avosetta: distribution pattern and correlates
}

Rémi Chambon, Sébastien Dugravot, Jean-Marc Paillisson, Jean-Christophe Lemesle, Fréderic Ysnel, Guillaume Gelinaud

\section{To cite this version:}

Rémi Chambon, Sébastien Dugravot, Jean-Marc Paillisson, Jean-Christophe Lemesle, Fréderic Ysnel, et al.. Partial migration in inexperienced pied avocets Recurvirostra avosetta: distribution pattern and correlates. Journal of Avian Biology, 2018, 49 (6), pp.01549. 10.1111/jav.01549 . hal-01860879

HAL Id: hal-01860879

https://hal-univ-rennes1.archives-ouvertes.fr/hal-01860879

Submitted on 28 Aug 2018

HAL is a multi-disciplinary open access archive for the deposit and dissemination of scientific research documents, whether they are published or not. The documents may come from teaching and research institutions in France or abroad, or from public or private research centers.
L'archive ouverte pluridisciplinaire HAL, est destinée au dépôt et à la diffusion de documents scientifiques de niveau recherche, publiés ou non, émanant des établissements d'enseignement et de recherche français ou étrangers, des laboratoires publics ou privés. 
Partial migration in inexperienced Pied avocets (Recurvirostra avosetta): distribution pattern and correlates

Rémi Chambon ${ }^{1}$, Sébastien Dugravot $^{1}$, Jean-Marc Paillisson ${ }^{2}$, Jean-Christophe Lemesle $^{3}$, Frédéric Ysnel ${ }^{1}$ and Guillaume Gélinaud ${ }^{4,5}$

${ }^{1}$ EA 7462 G-TUBE - Biodiversité et Gestion des Territoires, Université de Rennes 1, Rennes, France

${ }^{2}$ UMR 6553 ECOBIO CNRS/Université de Rennes 1, Rennes, France

${ }^{3}$ Réserve Naturelle de Lilleau des Niges, LPO, Les Portes-en-Ré, France

${ }^{4}$ EA 7462 G-TUBE, Université de Bretagne Occidentale UFR Sciences et Techniques, Brest, France

${ }^{5}$ Réserve Naturelle des Marais de Séné, Bretagne Vivante/SEPNB, Séné, France

Corresponding author: Rémi Chambon, EA 7462 G-TUBE - Biodiversité et Gestion des Territoires, Université de Rennes 1, Rennes, France. Email address: remi.chambon.1@gmail.com

Decision date: 24-Jan-2018 


\section{Abstract}

Birds exhibit a range of wintering behaviour from strictly migrant to strictly resident species. In partially migrating ones, some birds overwinter within their breeding region (resident birds) while others, although breeding in the same area, winter far away (migrant birds). Accordingly, choosing a wintering region is a key stage in the annual life cycle of birds, notably for inexperienced first-year individuals. The present study aimed to investigate this issue, and more specifically to study the distribution pattern during winter and factors influencing the wintering behaviour of first-year Pied avocets, Recurvirostra avosetta. Based on a 10-year ringing study carried out on five of the major breeding colonies distributed along the Atlantic coast, we showed the coexistence of different wintering tactics. The resident tactic was predominant (approximately 85\% of the 575 birds re-sighted), while the other birds adopted migration. Among resident individuals, two different tactics occurred: $43 \%$ of birds overwintered within their natal colony, whereas the others wintered in another site located at relatively close proximity along the French Atlantic coast. Hatching date was a consistent predictor of all wintering tactics. More specifically, the probability of migrating was the highest for early-hatched birds, and for resident ones, the probability of wintering within their natal colony rather than in another French site was the highest for both median- and latehatched individuals. In addition, a colony effect was demonstrated for resident birds. Several biological interpretations, including social system, variations in both individual body condition and habitat quality, were put forward to explain these correlates. 


\section{Introduction}

Winter quarter selection is a major event in the annual life cycle of birds. Environmental conditions experienced within wintering grounds (e.g. habitat quality and predation risk) and travel costs (notably energetic expense) to reach distant sites are known to strongly impact individual fitness (i.e. survival and upcoming reproductive success, Marra et al. 1998, Alerstam et al. 2003, Norris et al. 2004, Lok et al. 2011, Alves et al. 2013) and ultimately, population dynamics (Adriaensen and Dhondt 1990, Norris and Marra 2007). Partial migration is a behavioural dimorphism commonly displayed by bird species (Lack 1943, Newton 2008, Dingle 2014). It implies that some individuals overwinter in their breeding region (called resident or sedentary birds) while others leave it to reach geographically disjunct and distant quarters during the winter (migrant birds).

Several hypotheses have been explored to explain this pattern, suggesting a continuum in the control of the migratory tendency from obligate to facultative partial migration among bird species (Lundberg 1988, Newton 2008, Chapman et al. 2011 for a recent review, Hegemann et al. 2015). In the case of obligate partial migration, individual differences in wintering behaviour are supported by genetic determinism and result in two different phenotypes (i.e. resident and migratory strategies) which are fixed over the lifetime of individuals (Biebach 1983, Lundberg 1987, Lundberg 1988, Berthold 2001). Alternatively, facultative partial migration is considered as a conditional strategy providing two ecophenotypes (i.e. resident and migratory tactics) which can alternate during the lifetime of individuals (Ketterson and Nolan 1983, Lundberg 1987, Lundberg 1988, Chapman et al. 2011, Alcock 2013). More precisely, any selected tactic is expected to mainly result from the combined influences of environmental conditions (e.g. density-dependence, climatic conditions, Newton 2008, 
Vélez-Espino et al. 2013) and individual differences in some traits for example body size/condition and dominance status (Ketterson and Nolan 1976, Gauthreaux 1982, Lundberg 1985, Pérez-Tris and Telleria 2002, Hegemann et al. 2015).

Overall, factors driving facultative partial migration are thought to vary according to species ecology (e.g. social system) and to the status of individuals (e.g. age/experience). For inexperienced birds, leaving breeding grounds or not when winter approaches, represents one of their first crucial decisions (Sans-Aguilar et al. 2012), and hatching date and body condition at fledging are two of the main determinants of the wintering behaviour. In the Blue tit, Cyanistes caeruleus, Smith and Nilsson (1987) showed that late-hatched males were more inclined to migrate than early-hatched ones. However, Adriaensen (1986) observed the opposite pattern in the European robin, Erithacus rubecula. Since many passerine species display a strong territorial behaviour throughout the annual cycle (e.g. Schwabl 1992, Stutchbury 1994, Cuadrado 1995), competition for food resources was assumed to be involved in both species (Schwabl and Silverin 1990). The basis of the difference reported here on the hatching date effect between these two species is probably linked to variations in their respective ecology and in the strength of agonistic interactions between individuals and age classes (Schwabl and Silverin 1990). Colwell et al. (2007) found that the probability of migration during the first winter in the Snowy plover, Charadrius alexandrines nivosus, a gregarious species, was higher for early-hatched birds. The authors suggested that this tendency was related to social determinants. In addition, Barbraud et al. (2003) highlighted that young Greater flamingos, Phoenicopterus ruber, in good condition at fledging had a higher probability of leaving their natal region during their first winter and travelled over long distances to reach a wintering area. 
The Pied avocet, Recurvirostra avosetta, is a gregarious shorebird species (Recurvirostridae, Cramp and Simmons 1983), with a relatively wide range (from western Eurasia to Africa, Hötker and Dodman 2009). Birds of the western European breeding population mainly winter in a few typical coastal grounds (mostly inter-tidal mudflats and lagoons) distributed along the Atlantic coast of western Europe and also the western coast of north Africa (Hötker and Dodman 2009). However, different migratory tendencies occur among its constituent subpopulations. There is evidence of partial migration in the British subpopulation, although neither a quantitative assessment of the proportion of resident and migrant birds nor the associated factors determining wintering behaviour were provided (West 2005). Conversely, Danish and German subpopulations are strictly migrant (Salvig 1995, Hötker 1998, 2002). Furthermore, first-year individuals originating from the Wadden Sea were found wintering in different regions according to the severity of winter (Hötker 1998). The latter result clearly suggests that environmental conditions could affect wintering ground selection and probably, more generally, the choice of the migratory behaviour in this species.

Concerning the French Atlantic subpopulation, first-year Pied avocets are assumed to be partial migrants (Hötker and Dodman 2009) but this has previously never been documented. Here, we specifically addressed this issue using data from a 10-year ringing program carried out in five of the major French Atlantic breeding colonies. Our data provide a unique opportunity to examine wintering destinations on both large and fine spatial scales and to test for a facultative partial migration pattern. Our main objectives were thus twofold: (i) to analyse the distribution pattern of birds during their first winter - this notably consisted of quantifying the proportion of individuals adopting each wintering tactic and also testing for the occurrence of a spatial structure 
between the French natal colonies and the wintering grounds, and (ii) to explore the influence of factors that might account for the choice of a wintering tactic, including context-dependent and intrinsic variables.

\section{Methods}

\section{Study sites and fieldwork}

\section{Breeding colonies}

From 2006 to 2015, a joint ringing study was conducted within five major breeding colonies of Pied avocets located along the French Atlantic coast (Fig. 1): (i) the gulf of Morbihan (thereafter called Morbihan), (ii) the marshes of Mesquer (Mesquer), (iii) the marshes of Guérande (Guérande), (iv) the bay of Bourgneuf including the island of Noirmoutier (Bourgneuf), and (v) the island of Ré (Ré). Each colony included a wetland area composed of habitats actively used by Pied avocets during the breeding period man-made habitats such as salt pans. Colonies were separated by unsuitable habitats and distances between them ranged from 12 to $207 \mathrm{~km}$ (orthodromic distances).

\section{Capture and ringing}

Every year (except in 2007 and 2012, respectively for Bourgneuf and Morbihan), chicks were captured by hand at an estimated age of 20 to 30 days (i.e. just before fledging) between April and August. Once captured, each bird was ringed with a unique colour combination fixed onto the two tibiotarsi, plus a metal ring from the French Ringing Scheme (C.R.B.P.O.) on one of the tarsometatarsi. Chicks were then weighed, using a spring balance (in $\mathrm{g}, \pm 0.1 \mathrm{~g}$ ). Both the bill length (from the tip of the upper mandible to the base of the first feathers of the skull) and the tarsus length (from the notch of the intertarsal joint to the base of the $90^{\circ}$ bent foot) were measured, using a Vernier calliper (in $\mathrm{mm}, \pm 0.1 \mathrm{~mm}$ ). The wing length (from the bend of the wing to the tip of the longest primary feather) was also taken, using a metallic stop ruler (in $\mathrm{mm}, \pm 0.5 \mathrm{~mm}$ ). Given 
the lack of sexual dimorphism, the gender of chicks could not be determined. Finally, spatial coordinates of the capture location of all ringed birds were recorded. For Morbihan, Mesquer and Guérande, ringed chicks represented more than $50 \%$ of the fledglings over the study period (we have no such estimates for the other two colonies).

\section{Winter re-sightings}

Thanks to a large network of professional and amateur ornithologists, French-ringed Pied avocets have been observed across the wintering range of the western European breeding population (Hötker and Dodman 2009). During winter, birds are mainly observed foraging in flocks on intertidal mudflats, coastal lagoons, salt pans and, to a lesser extent, in fishponds and shallow lakes, depending on the locations (Hötker and Dodman 2009). Concerning the French Atlantic coast, birds were observed in relatively few sites that are regularly used by the Pied avocet during winter. Nine of these sites usually support more than $90 \%$ of birds wintering in France (Mahéo et al. 2007). Among them are notably the five wetlands also used as breeding grounds (Morbihan, Mesquer, Guérande, Bourgneuf and Ré). Birds were also observed in northwest Europe, across the Iberian Peninsula and along the west coast of northern Africa. Since most of the French wintering sites are included in protected areas, birds were routinely observed by both the local staff of managers and our research team. Consequently, the re-sighting effort during winter was considered to be relatively more intensive in France when compared to the other regions, and was comparable between years. Also, fieldwork was very regular outside France, notably in the Iberian Peninsula where the major wintering sites were visited for a period of several weeks every year. In Africa, the observation effort was much less intensive and less regular from year to year.

\section{Data selection}


We restricted investigations to the re-sightings collected during the first winter of ringed birds (from winter 2006/2007 up to winter 2015/2016). Since only three birds were recorded in Africa, re-sightings from this region were excluded from the dataset. Based on the distances recorded between capture and wintering locations, first-year individuals were categorized into three groups corresponding to three different wintering tactics: (i) birds wintering within their natal colony (called strictly resident birds), (ii) individuals wintering in a site located on the French Atlantic littoral, but not in their natal colony (called locally resident birds, orthodromic distance $<320 \mathrm{~km}$ ), and (iii) birds observed farther away (called migrant birds, see Supplementary material Appendix 1, Fig. A1) either in the south of the Iberian Peninsula $(>1030 \mathrm{~km})$ or in northwest Europe - more exactly in the United-Kingdom, after crossing the British Channel (> $350 \mathrm{~km})$ or along the North Sea coast (> $690 \mathrm{~km}$ ). Distances travelled by migrant birds (orthodromic distances) were probably underestimated if one considers that individuals mainly follow the littoral for their journey. Additionally, natal and wintering grounds reached by migrant birds were separated by wide areas of unsuitable habitats. The first two categories (strictly and locally resident birds) have also been defined in this way elsewhere (see for instance Adriaensen and Dhondt 1990). Re-sightings of migrant Pied avocets occurred from $1^{\text {st }}$ November to $31^{\text {th }}$ March. Based on the range of migratory timing in our database (irrespective of bird age), individuals re-sighted in France from $20^{\text {th }}$ December to $25^{\text {th }}$ February were defined as resident birds with high certainty.

The dataset analyzed was composed of 575 first-year Pied avocets (i.e. 28.9\% of the total number of chicks ringed from 2006 to 2015) observed during their first winter. The number of individuals originating from the five breeding colonies ranged from 55 to 179 (see details in Fig. 1). Based on survival probabilities calculated between the capture period and the beginning of the subsequent winter (unpublished data), we 
estimated that our sample size represented approximately $45 \%$ of ringed birds likely to be alive in their first winter. In cases of multiple re-sightings $(55 \%$ of birds were observed from two to a maximum of 21 times during winter), one location was randomly selected to assign spatial coordinates to each individual for spatial analyses. Each migrant bird was observed in a unique wintering region (i.e. there was no movement between northwest Europe and the Iberian Peninsula regions during a given winter). A small fraction of resident birds (5.3\%) was observed in two different wintering sites. In this case, we selected the location whose re-sighting date was the closest to $15^{\text {th }}$ January (the middle date of the wintering period). In the statistical analyses, no distinction was made between years (i.e. all years were pooled): it could have been appropriate to explore a year effect if for example, severe winter conditions had occurred during the study period, but that was not the case.

\section{Statistical analyses}

\section{Distribution pattern of wintering birds}

We firstly carried out a set of comparisons, using Binomial tests of equality: the proportions of migrant and resident birds (strictly and locally resident individuals pooled), the proportions of migrant birds according to their wintering region (northwest Europe or the Iberian Peninsula), and the proportions of strictly and locally resident birds.

Then, we explored whether a spatial structure occurred for different groups of birds, by looking for a preferential winter distribution with respect to their natal origin. For migrant birds, we investigated the relationship between their origin (five natal colonies) and their wintering regions (northwest Europe or the Iberian Peninsula) using a Fisher's exact test of independence. For locally resident birds, we used a Mantel test which is particularly relevant in the case of mapped point data as it occurred here. We 
followed the method used by Ambrosini et al. (2009) to study migratory connectivity. For this, two matrices of orthodromic distances were built: one composed of interindividual distances calculated from the location of birds at the time of capture and a similar one based on wintering locations. A Mantel test (with 9999 random permutations) was then performed; it consisted of regressing wintering distances against natal distances. When significantly positive, a correlation (Mantel coefficient: $r_{m}$ ranging from -1 to +1 ) means that birds captured at close distances overwinter at close distances too. Additionally, we tested whether distances travelled by birds between their capture and wintering locations varied according to the natal colony, using a Mood test (a non-parametric median test) for the global test, and a Mood test with a false discovery rate correction for post-hoc pair-wise comparisons.

\section{Correlates to wintering tactics}

We investigated the influence of several variables on the probability of a bird (i) displaying migrant behaviour (migrant vs resident birds, thereafter called 'Migrant model'), or (ii) being strictly resident when wintering in France (strictly resident vs locally resident birds, thereafter called 'Strictly resident model'), using Generalized Linear Models (GLMs) with Binomial error family and logit link-function. In the 'Migrant model', we did not differentiate wintering regions (northwest Europe or the Iberian Peninsula). We explored the effects of two context-dependent and one intrinsic candidate explanatory variables. As context-dependent variables, we used natal colony ( $\mathrm{n}=5$ colonies) and hatching date within season $(\mathrm{n}=3$ categories). Hatching date of chicks was derived from the estimation of chick age when captured using a reversed logistic growth regression (see Supplementary material Appendix 2, Fig. A2) applied to bill length ( $\mathrm{n}=557$ individuals). Finally, estimated hatching dates were classified into three groups: early- (33.9\% of the total number of chicks), median- $(44.7 \%)$ and late- 
hatched (21.4\%) birds (see Supplementary material Appendix 2, Fig. A3). This categorization was consistent according to years and colonies. The body condition of chicks at capture was the only intrinsic variable tested. For this, a Principal Component Analysis (PCA) was performed on body size variables (bill, wing and tarsus lengths). Then, a second step consisted of regressing body mass of chicks against individual component scores from the first axis of the multivariate analysis (as recommended by Schulte-Hostedde et al. 2005). The first axis explained $76.5 \%$ of the variance in chick body size. Lastly, residuals of the regression $\left(\mathrm{R}^{2}=0.56,1\right.$ and $554 \mathrm{DF}, F=696.7, \mathrm{p}<$ 0.001 ; estimated slope $\pm \mathrm{SE}=14.06 \pm 0.53, t=26.4, \mathrm{p}<0.001$, estimated intercept $=$ $190.08 \pm 0.81, t=235.3, \mathrm{p}<0.001, \mathrm{n}=556$ chicks) were used as a body condition index of chicks at the time of capture (values ranging from -105.3 to 83.8). However, body condition index was dependent on both natal colony and hatching date (two permutation tests, see the Results for details) and was thus removed from the set of explanatory variables finally tested in the GLMs in order to minimize statistical biases in the variable selection process. Post-hoc permutation tests (using the false discovery rate method) allowed us to determine how the body condition index varied according to each level of both natal colony and hatching date variables (see the Results).

Because of a few missing values for the hatching date variable, the 'Migrant model' and 'Strictly resident model' were respectively performed on a total of 557 and 475 birds. For each GLM, the effect of natal colony and hatching date, and their interaction were tested. Tests of Type II were carried out and non-significant terms were removed from each model. Based on the least squares means (LSMeans) we performed pair-wise post-hoc Tukey comparisons of significant variables in both models. The LSMeans were used to provide adjusted probabilities by taking the effect of each significant variable into account. 
All statistical analyses were carried out using $\mathrm{R}$ version 3.3.1 (R Core Team 2016) and the 'ade4', 'car', '1smeans', 'mixtools', 'RVAideMemoire' and 'sp' libraries. The significant level was fixed at $\alpha=0.05$.

\section{Results}

\section{Distribution pattern of wintering birds}

From a total of 575 Pied avocets re-sighted during their first winter, most of them were resident $(85.6 \%)$ while the others $(14.4 \%)$ were migrant (Binomial test of equality, $\mathrm{p}<$ 0.001). Migrant individuals wintered predominantly across the Iberian Peninsula ( $80.7 \%$, Binomial test of equality, $\mathrm{p}<0.001)$, and more precisely in southern Portugal and along the south-western coast of Spain (see Supplementary material Appendix 1, Fig. A1). The other migrant birds wintered across northwest Europe (19.3\%), mainly along the English Channel in the south of the United Kingdom and to a minor extent in the Netherlands and Germany. Concerning resident birds, the proportion of individuals wintering in their natal site $(43.1 \%)$ was significantly lower than that of locally resident birds (56.9\%, Binomial test of equality, $\mathrm{p}=0.002)$.

Natal colony did not influence the distribution of migrant birds between the two European regions reached (northwest Europe and the Iberian Peninsula, Fisher's exact test of independence, $\mathrm{p}=0.19)$. Median travelled orthodromic distances $( \pm$ MAD Median Absolute Deviation) were $512.32 \pm 125.12 \mathrm{~km}$ and $1102.07 \pm 72.88 \mathrm{~km}$ for birds wintering in the northwest Europe and in the Iberian Peninsula, respectively. Resident birds were recorded in 11 distinct French sites (Fig. 2). At first sight, there was evidence for a preferential distribution of birds in the vicinity of their natal colony during winter (Fig. 2). In other words, most birds originating from a given colony were recorded during winter either in the same place or within nearby sites. Indeed, for locally resident birds, individuals captured at close distance to each other tended to 
winter at relatively short distance to each other (Mantel test, $\mathrm{r}_{\mathrm{m}}=0.28, \mathrm{p}<0.001$ ). Additionally, locally resident birds were observed at a distance of $31.96 \pm 25.42 \mathrm{~km}$ (median \pm MAD, orthodromic) from capture locations $(2.81 \pm 2.25 \mathrm{~km}$ for strictly resident birds), with differences depending on the natal colony (Mood test, $4 \mathrm{DF}, \chi^{2}=$ 82.91, $\mathrm{p}<0.001)$. More precisely, the median distance travelled by locally resident birds was higher (from post-hoc comparisons) for birds originating from Bourgneuf and Ré $(74.86 \pm 34.76 \mathrm{~km}$ and $103.09 \pm 86.35 \mathrm{~km}$, respectively) than for birds originating from Morbihan and Guérande $(36.16 \pm 14.86 \mathrm{~km}$ and $36.12 \pm 13.18 \mathrm{~km}$, respectively). The lowest median distance was found for birds originating from Mesquer $(15 \pm 6.53$ $\mathrm{km})$.

\section{Correlates to wintering tactics}

For first-year Pied avocets, the probability of migrating rather than being resident ('Migrant model') was not influenced by the colony of origin, but it was significantly associated with hatching date. More specifically, the probability of migrating was higher for early-hatched birds (probability $\pm \mathrm{SE}=0.23 \pm 0.03$ ) than for median- and late-hatched birds $(0.12 \pm 0.02$ and $0.08 \pm 0.02$, respectively, Table 1 and Fig. 3). Among first-year birds wintering in France, the probability of being strictly resident rather than locally resident ('Strictly resident model', Table 1 and Fig. 4A) was significantly lower for birds originating from Mesquer and Ré $(0.22 \pm 0.03$ and $0.30 \pm$ 0.06 , respectively) than for birds originating from the other three colonies for which estimates were similar (ranging from $0.57 \pm 0.04$ to $0.62 \pm 0.06$ ). Furthermore, earlyhatched birds exhibited a significantly lower probability $(0.32 \pm 0.04)$ than median- and late-hatched individuals $(0.45 \pm 0.04$ and $0.59 \pm 0.05$, respectively) of being strictly resident rather than locally resident (Table 1 and Fig. 4B). 
As already mentioned, body condition index was significantly influenced by natal colony (permutation test: $\mathrm{n}=556, F=26.69, \mathrm{DF}=4, \mathrm{p}=0.001$ ): body condition index of birds hatched in Ré (mean $\pm \mathrm{SE}=-16.93 \pm 2.04$ ) was significantly lower than for birds hatched among the four other colonies for which condition was statistically similar (mean values ranging from $0.20 \pm 1.88$ to $5.50 \pm 1.32$ ). Furthermore, analyses showed that body condition index varied significantly according to the hatching date of birds (permutation test: $\mathrm{n}=555, F=22.92, \mathrm{DF}=2, \mathrm{p}=0.001$ ). The three two-by-two post-hoc tests were significant: body condition index was the highest for early-hatched birds $($ mean $=6.46 \pm 1.24)$, the lowest for median-hatched individuals $($ mean $=-5.11 \pm$ $1.12)$, and intermediate for late-hatched ones (mean $=1.34 \pm 1.77)$.

\section{Discussion}

The present study clearly demonstrates that first-year Pied avocets originating from the French Atlantic subpopulation display a partial migration pattern. More precisely, we showed that most of the birds were either strictly or locally resident, while only approximately $14 \%$ were migrant, mainly joining wintering grounds in the Iberian Peninsula or, to a lesser extent, in northwest Europe. To our knowledge, this is the first time that quantitative data has been provided on partial migration in a Pied avocet subpopulation of western Europe. Conversely, German and Danish Pied avocets were found to be strictly migrant (Salvig 1995, Hötker 1998, 2002). A possible explanation for this variation in the migratory tendency between Pied avocet subpopulations might arise from differences in weather conditions during winter. Indeed, severe winter conditions are known to trigger a decrease in habitat suitability (notably a decrease in food resources) and would promote migration in birds (Lundberg 1988, Newton 2008). Overall, weather conditions experienced in France during winter are less severe than in regions located at higher latitudes as in Germany and Denmark. In addition, since 
relatively clement winters were noted during the study period, this could explain why most of the French first-year Pied avocets stayed in France.

A second major result was that early-hatched Pied avocets had a higher probability of migrating (migrant tactic) compared to other birds even if only a small proportion of them migrated. A biological interpretation could be that early-hatched birds are in better condition (i.e. they have more fat reserves, see Merilä and Svensson 1997) at the time of migration departure and thus are able to bear the cost of travelling long distances to reach wintering quarters. Two main reasons, potentially acting in synergy, can explain this fact. Firstly, we showed that early-hatched birds were in better condition at fledging, a result which could be explained by the higher availability of high-quality rearing grounds (notably regarding food resources, Adret 1983) for early broods. If the inter-individual differences in body condition are maintained from fledging until migration departure, as demonstrated in another avian species (Merilä and Svensson 1997), it could explain the relationship found between hatching date and migration propensity. This is consistent with the role of body and local environmental conditions on post-fledging movements suggested in the Greater flamingo (Barbraud et al. 2003). Secondly, early-hatched birds had more time to build up reserves compared to later-hatched individuals, making the former more inclined to undertake a costly migratory journey (Pierce 1989). Colwell et al. (2007) suggested that early-hatched Snowy plovers, another gregarious shorebird species, developed a migrant behaviour by wandering to join conspecific postnuptial flocks outside their own colony in which most birds were still raising their chicks or attempting to breed. In contrast, later-hatched birds would be directly incorporated at fledging into wintering flocks within their natal colony, promoting their resident behaviour (Colwell et al. 2007). Pied avocets also display post-nuptial flocks (Cramp and Simmons 1983, personal obs.). However, given 
the distribution (i.e. close proximity) of sites used by early post-nuptial flocks in the neighbourhood of the five colonies studied, it is unlikely that the wandering of earlyhatched birds to join groups would promote migration as suggested in the hypothesis put forward by Colwell et al. (2007).

Complementarily, we distinguished two wintering tactics among resident individuals: strictly resident birds (43\%) wintering within their natal colony, and locally resident birds (57\%) wintering in other French sites. For locally resident birds, we found that the distance travelled between capture and wintering locations fluctuated according to the natal colony. These variations are probably due to the heterogeneous distribution of suitable wintering sites in the vicinity of the natal colonies. For instance, these distances are greater for birds hatched in Bourgneuf and Ré which are the most isolated grounds from other suitable wintering sites (see Figure 2). While we did not provide evidence of any preferential wintering destination for migrant birds according to their natal colony, we found that locally resident birds wintered preferentially in a few sites located in very close vicinity to their natal colony. Additionally, we showed that the probability of resident birds wintering within their colony of origin varied according to the natal colony: it was lower for birds from Mesquer and Ré (about 25\% vs $60 \%$ for the three other colonies). Differences in carrying capacity between these five wintering sites might explain this result, due to a density-dependent process known to influence facultative partial migration (Vélez-Espino et al. 2013). Mesquer and Ré support a lower proportion of the almost 20000 Pied avocets wintering annually in France when compared to the three other sites (2-3\% vs $6-14 \%$, Wetland International databases). That might mean that Mesquer and Ré are less suitable habitats at that time when competition for food resources is likely to be exacerbated, and maybe also during the breeding period. Indeed, birds originating from Ré had a lower body condition. 
Furthermore, we showed that early-hatched birds had a lower probability of being strictly resident as compared to median and late-hatched ones. As already discussed, body condition is correlated with hatching dates and might thus affect the choice between the two resident tactics. Nevertheless, its influence on wintering decisions is probably less important for resident birds than for migrant ones (i.e. very short vs long distances to reach wintering sites). Moreover, resident birds hatched in Ré displayed a low body condition and a low probability of being strictly resident. Therefore, we suggest that the effect of hatching date might be related to the specific social behaviour already mentioned (Colwell et al. 2007). By wandering in the vicinity of their natal colony searching to join post-nuptial flocks, early-hatched Pied avocets would have more opportunities to reach high-quality sites to overwinter, whereas later-hatched individuals would stay with conspecifics within their natal colony, increasing their probability of becoming strictly resident.

\section{Conclusion}

We demonstrated that first-year French Pied avocets display a partial migration pattern in contrast with what has been found among some of the other western European subpopulations for both inexperienced birds (Hötker 1998) and adults (Salvig 1995, Hötker 1998, 2002). More precisely, we showed that most of the birds were resident, overwintering either in their natal colony or in a relatively close wintering site. In addition, we showed the influence of two context-dependent variables, hatching date being a consistent predictor of all wintering tactics. For this latter, underlying associated factors explaining wintering behaviours might differ according to tactics. For instance, the effect of body condition of birds on the decision to migrate is strongly suspected, and social behaviours would be predominant for the choice 
between the two resident tactics. Based on our findings, we can hypothesize that inexperienced first-year French Pied avocets display a facultative partial migration. Nevertheless, additional relevant factors necessary to clarify the control of the wintering behaviour effectively may be missing (e.g. genetic factors, sex, immune function and personality: Biebach 1983, Chapman et al. 2011, Hegemann et al. 2015, Nilsson et al. 2016). An exploration of the fitness consequences in terms of survival and reproductive success would be very helpful to evaluate the differences between the wintering tactics. In the case of facultative partial migration, the fitness of the different wintering categories would not necessarily be equal and may notably vary according to environmental conditions (Lundberg 1988, Gillis et al. 2008). Therefore, the study of the degree of individual lifetime fidelity (or flexibility) to wintering tactics would also be a perspective of major interest. Additionally, further investigation is needed to determine whether resident tactics promote breeding philopatry. All these issues would contribute to our understanding of the demographic mechanisms involved in the growth of the French breeding subpopulation since its settlement during the middle of the $20^{\text {th }}$ century (Hötker and West 2005, BirdLife International 2015).

\section{Acknowledgements}

We thank the Avocet field teams of the 2006-2015 period for their invaluable assistance in the field, both in France and abroad, and the many more birdwatchers for colour-ring re-sightings across the flyway. We particularly thank Frédéric Touzalin, Alain Gentric, Julien Gernigon, François Hémery, Loïc Jomat, Fabien Mercier, Jean-Guy Robin, Franck Salmon and Matthieu Vaslin for their ringing skills and the following nature reserves involved in the Pied avocet program: Réserve naturelle des marais de Séné, 
Réserve Naturelle du marais de Müllembourg, Réserve naturelle de Lilleau des Niges, and Réserve naturelle de Moëze-Oléron. José Alves, Claudine de le Court and Alfonso Rocha helped with logistics and access to the staging sites in Portugal and Spain. We are grateful to Maxime Hervé for constructive advice on statistical analyses. This research was supported by the Ministère de l'Education Nationale, de l'Enseignement Supérieur et de la Recherche (Ph.D. grant to R.C.). This work was done under the license of C.R.B.P.O. - Museum National d'Histoire Naturelle. Lastly, we are grateful to the two anonymous reviewers and Jan-Åke Nilsson for their constructive comments on an earlier version of the manuscript. Aldyth Nys edited the final version of the manuscript. 


\section{References}

Adret, P. 1983. Une étude des comportements parentaux de l'avocette en colonie de reproduction. Organisation spatial inter- et intra-familiale. - Can. J. Zool. 61: 603-615.

Adriaensen, F. 1986. Differences in migratory behaviour between early and late brood nestlings of the robin Erithacus rubecula. - Ibis 129: 263-267.

Adriaensen, F. and Dhondt, A. A. 1990. Population dynamics and partial migration of the European robin (Erithacus rubecula) in different habitats. - J. Anim. Ecol. 59: 1077-1090.

Alcock, J. 2013. Animal behavior: an evolutionary approach - Sunderland, U.S.A.

Alerstam, T., Hedenström, A. and Åkesson, S. 2003. Long-distance migration: evolution and determinants. - Oikos 103: 247-260.

Alves, J. A., Gunnarsson T. G., Hayhow, D. B., Appleton, G. F., Potts, P. M., Sutherland, W. J. and Gill. J. A. 2013. Costs, benefits, and fitness consequences of different migratory strategies. - Ecology 94: 11-17.

Ambrosini, R., Moller, A. P. and Saino, N. 2009. A quantitative measure of migratory connectivity. - J. Theor. Biol. 257: 203-211.

Barbraud, C., Johnson, A. R. and Bertault, G. 2003. Phenotypic correlates of postfledging dispersal in a population of greater flamingos: the importance of body condition. - J. Anim. Ecol. 72: 246-257.

Berthold, P. 2001. Bird migration: a general survey. - Oxford University Press.

Biebach, H. 1983. Genetic determination of partial migration in the European robin (Erithacus rubecula). - Auk 100: 601-606.

BirdLife International 2015. European Red List of Birds. - Luxembourg: Office for Official Publications of the European Communities. 
Chapman, B. B., Brönmark, C., Nilsson, J.-Å. and Hansson, L.-A. 2011. The ecology and evolution of partial migration. - Oikos 120: 1764-1775.

Colwell, M. A., McAllister, S. E., Millett, C. B., Transou, A. N., Mullin, S. M., Nelson, Z. J., Wilson, C. A. and LeValley, R. R. 2007. Philopatry and natal dispersal of the western snowy plover. - Wilson J. Ornithol. 119: 378-385.

Cramp, S. and Simmons, K. E. L. 1983. The birds of the western palearctic. - Oxford University Press, Vol. III., pp. 48-62.

Cuadrado, M. 1995. Winter territoriality in migrant black redstarts Phoenicurus ochruros in the Mediterranean area. - Bird Study 42: 232-239.

Dingle, H. 2014. Migration: the biology of life on the move. - Oxford University Press. Gauthreaux, S. A. Jr. 1982. The ecology and evolution of avian migration systems. - In: Farner, D. S. et al. (eds), Avian biology. Academic Press, pp. 93-168.

Gillis, E. A, Green, D. J., Middleton, H. A. and Morrissey, C. A. (2008). Life history correlates of alternative migratory strategies in American dippers. - Ecology 89: 16871695.

Hegemann, A., Marra, P. P. and Tieleman, B. I. 2015. Causes and consequences of partial migration in a passerine bird. - Am. Nat. 186: 531-546.

Hötker, H. 1998. Choice of winter quarters in Avocets (Recurvirostra avosetta). - Biol. Cons. Fauna. 102: 118-122.

Hötker, H. 2002. Arrival of Pied Avocets Recurvirostra avosetta at the breeding site: effects of winter quarters and consequences for reproductive success. - Ardea 90: 379387.

Hötker, H. and West, R. 2005. Population size, population development and habitat use of Avocets in Western Europe at the end of the 20th century. - Wader Study Group Bull. 107: 57-65. 
Hötker, H. and Dodman, T. 2009. Pied avocet Recurvirostra avosetta. - In: Delany, S. et al. (eds), An atlas of wader populations in Africa and western Eurasia. Wetlands International and International Wader Study Group, Wageningen, the Netherlands, pp. $63-71$.

Ketterson, E. D. and Nolan, V. Jr. 1976. Geographic variation and its climatic correlates in the sex ratio of eastern-wintering Dark-eyed Juncos (Junco hyemalis hyemalis). Ecology 57: 679-693.

Ketterson, E. D. and Nolan, V. Jr. 1983. The evolution of differential bird migration. In: Johnston, R. F. (ed), Current ornithology. Plenum Press, Vol. I., pp. 357-402.

Lack, D. 1943. The problem of partial migration. - Br. Birds 37: 122-130.

Lok, T., Overdijk, O., Tinbergen, J. M. and Piersma, T. 2011. The paradox of spoonbill migration: most birds travel where survival rates are lowest. - Anim. Behav. 82: 837844.

Lundberg, P. 1985. Dominance behaviour, body weight and fat variations, and partial migration in European blackbirds Turdus merula. - Behav. Ecol. Sociobiol. 17: 185189.

Lundberg, P. 1987. Partial bird migration and evolutionary stable strategies. - J. Theor. Biol. 125: 351-340.

Lundberg, P. 1988. The evolution of partial migration in birds. - Trends Ecol. Evol. 3: $172-175$.

Mahéo, R., Le Drean-Quenec'Hdu, S. and Triplet, P. 2007. L'Avocette élégante Recurvirostra avosetta hivernant en France (Littoral Manche-Atlantique), 1977-2005. Alauda 75: 38-48.

Marra, P. P., Hobson, K. A. and Holmes, R. T. 1998. Linking winter and summer events in a migratory bird by using stable-carbon isotopes. - Science 282: 1884-1886. 
Merilä, J. and Svensson, E. 1997. Are fat reserves in migratory birds affected by condition in early life? - J. Avian. Biol. 28: 279-286.

Newton, I. 2008. The migration ecology of birds. - Academic Press.

Nilsson, A. L. K., Nilsson J.-Å. and Mettke-Hofmann, C. 2016. Energy reserves, information need and a pinch of personality determine decision-making on route in partially migratory blue tits. - PLoS One 11: e0163213.

Norris, D. R., Marra, P. P., Kyser, T. K., Sherry, T. W and Ratcliffe, L. M. 2004. Tropical winter habitat limits reproductive success on the temperate breeding grounds in a migratory bird. - Proc. R. Soc. Lond. B. 271: 59-64.

Norris, D. R. and Marra, P. P. 2007. Seasonal interactions, habitat quality, and population dynamics in migratory birds. - Condor 109: 535-547.

Pérez-Tris, J. and Tellería, J. L. 2002. Migratory and sedentary blackcaps in sympatric non-breeding grounds: implications for the evolution of avian migration. - J. Anim. Ecol. 71: 211-224.

Pierce, R.J. 1989. Breeding and social patterns of banded Dotterels (Charadrius bicinctus) at Cass river. - Notornis. 36: 13-23.

R Core Team. 2016. R: A Language and Environment for Statistical Computing. R Foundation for Statistical Computing. Vienna, Austria. https://www.R-project.org/

Salvig, J. C. 1995. Migratory movements and mortality of Danish Avocets Recurvirostra avosetta. - Ring. \& Migr. 16: 79-90.

Sanz-Aguilar, A., Béchet, A., Germain, C., Johnson, A. R. and Pradel, R. 2012. To leave or not to leave: survival trade-offs between different migratory strategies in the greater flamingo. - J. Anim. Ecol. 81: 1171-1182. 
Schulte-Hostedde, A. I., Zinner, B., Millar, J. S. and Hickling, G. J. 2005. Restitution of mass-size residuals: validating body condition indices. - Ecology 86: 155-163.

Schwabl, H. and Silverin, B. 1990. Control of partial migration and autumnal behaviour. - In: Gwinner, E. (ed), Bird migration: physiology and ecophysiology. Springer, Berlin, pp. 144-155.

Schwabl, H. 1992. Winter and breeding territorial behaviour and levels of reproductive hormones of migratory european robins. - Ornis. Scand. 23: 271-276.

Smith, H. G. and Nilsson, J.-A. 1987. Intraspecific variation in migratory pattern of a partial migrant, the blue tit (Parus caeruleus): an evaluation of different hypotheses. Auk 104: 109-115.

Stutchbury, B. J. 1994. Competition for winter territories in a neotropical migrant: the role of age, sex and color. - Auk 111: 63-69.

Vélez-Espino, L. A., McLaughlin, R. L. and Robillard, M. 2013. Ecological advantages of partial migration as conditional strategy. - Theor. Popul. Biol. 85: 1-11.

West, R. 2005. Pied Avocets wintering in Britain, 1947-2001. - Wader Study Group Bull. 107: 54-56.

Supplementary material (Appendix JXXXXX at <www.oikosoffice.lu.se/appendix>). Appendix 1-2. 


\section{FIGURE LEGENDS}

Figure 1: Geographical location of (A) the breeding region of the Pied avocet along the French Atlantic littoral, and (B) the five French colonies studied. Numbers of first-year birds considered in this study are reported for each colony.

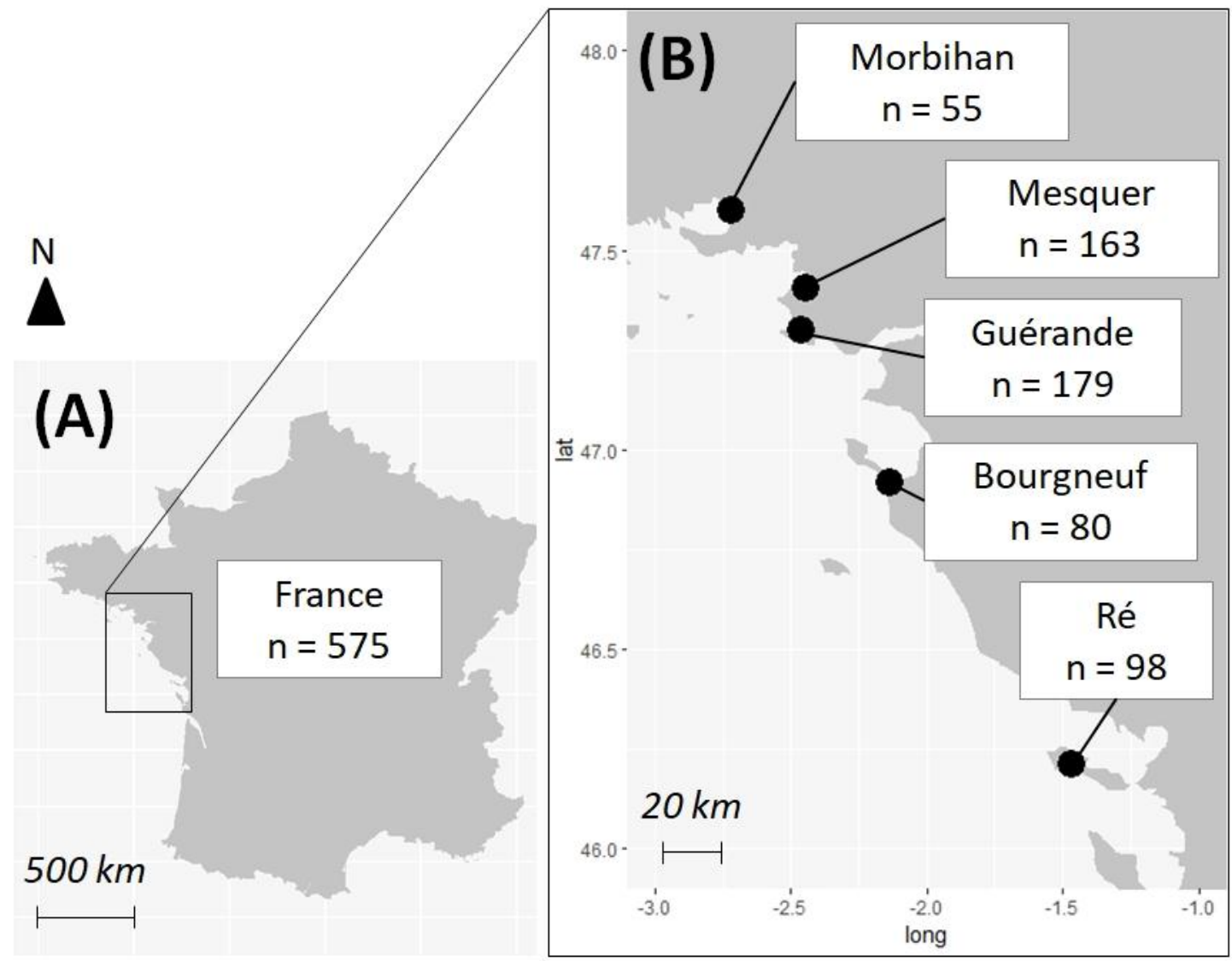


Figure 2: Distribution of resident Pied avocets $(n=492)$ among 11 wintering sites situated along the French Atlantic littoral (with decreasing latitudes: Morbihan, VilainePénerf, Mesquer, Guérande, Loire, Bourgneuf, Olonne, Aiguillon, Ré, Moëze-Oléron and Teich-Arcachon) according to their natal colony (shades from white to black). The numbers of birds re-sighted are reported for each wintering site.

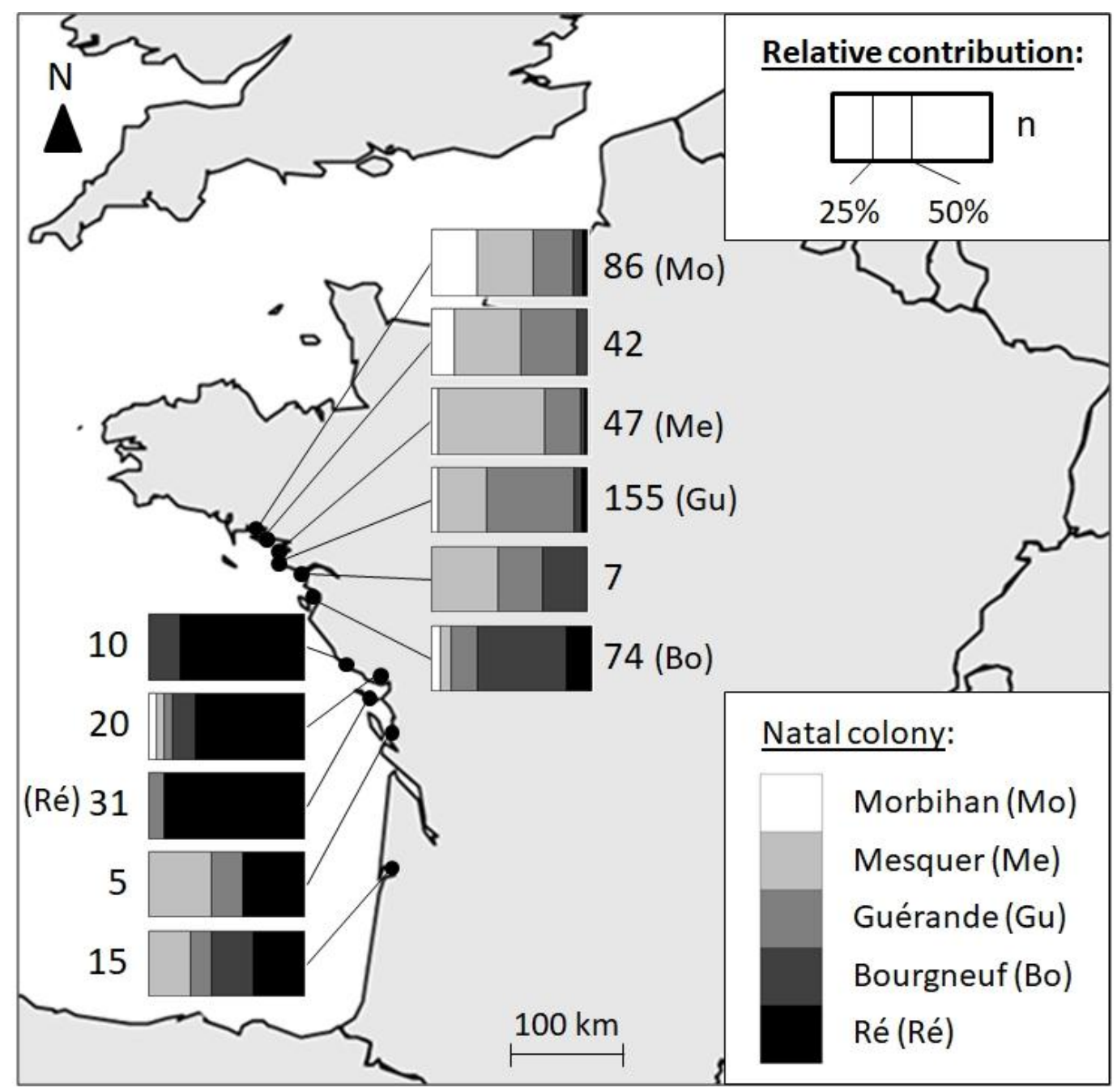


Figure 3: Probability of first-year Pied avocets migrating $(n=557)$ as a function of hatching date (expressed in three classes: early, median and late). Post-hoc significant differences were represented by different letters. Vertical lines represent $95 \%$ confidence intervals.

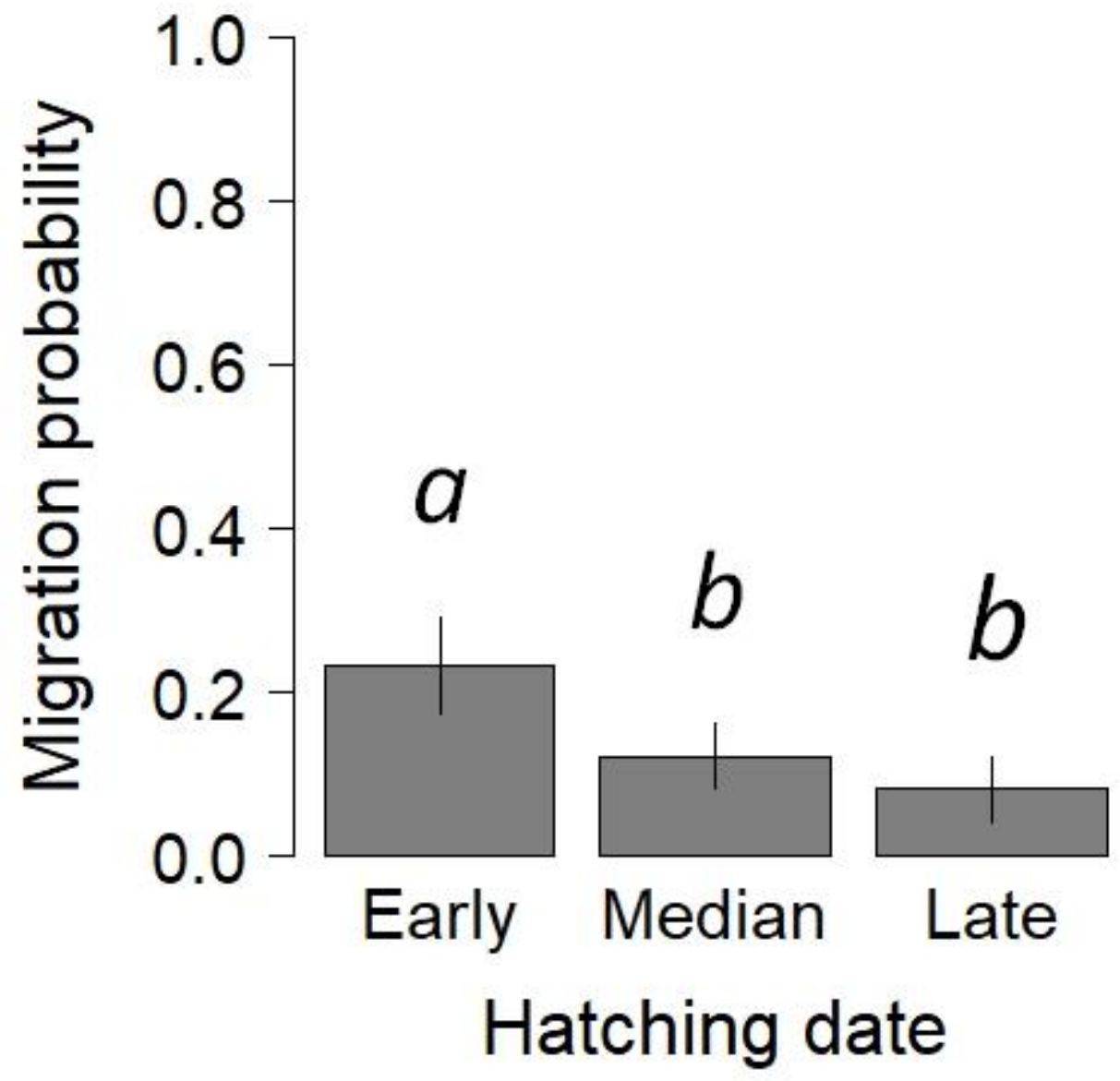


Figure 4: Probability of being strictly resident for first-year Pied avocets wintering in France $(\mathrm{n}=475)$ as a function of $(\mathrm{A})$ natal colony (five colonies), and (B) hatching date (expressed in three categories: early, median and late). Post-hoc significant differences were represented by different letters. Vertical lines represent $95 \%$ confidence intervals.
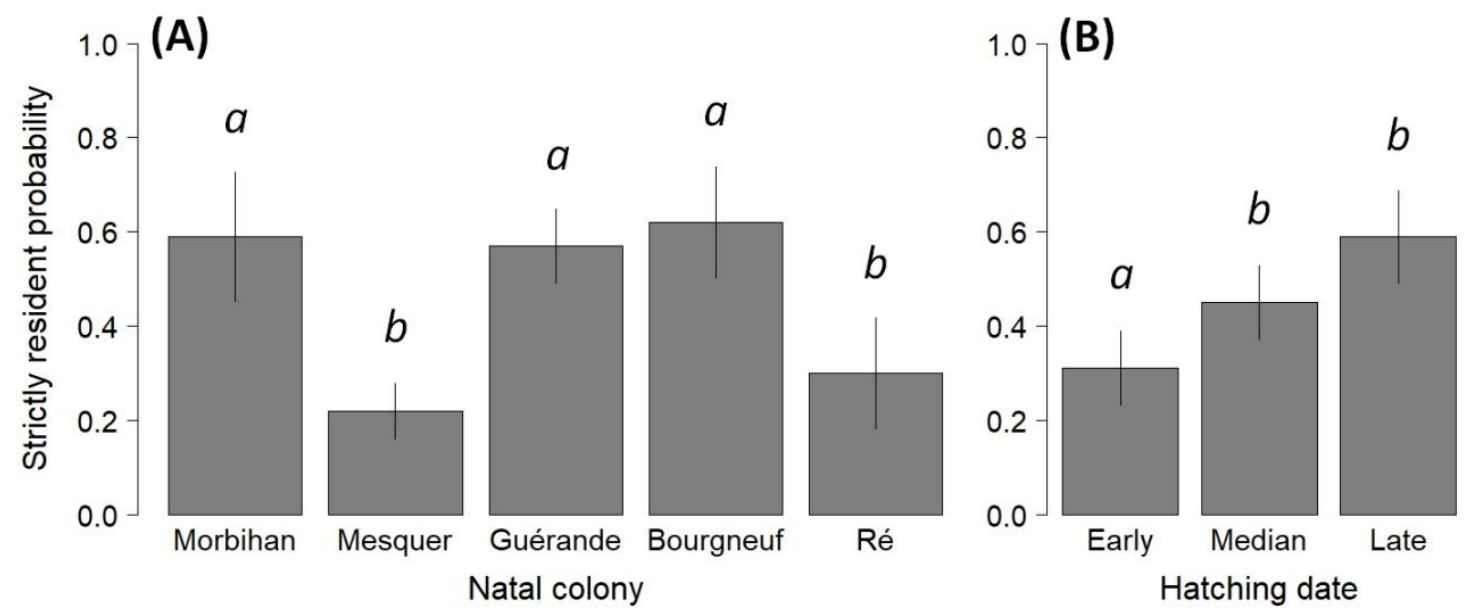


\section{TABLE LEGEND}

Table 1: Generalized Linear Models testing the simple and interaction effects of two explanatory variables on the probability of migrating for first-year Pied avocets $(n=$ 557, 'Migrant model'), and being strictly resident when wintering in France ( $\mathrm{n}=475$, 'Strictly resident model').

\begin{tabular}{|c|c|c|c|c|c|c|}
\hline \multirow[t]{2}{*}{ Effect } & \multicolumn{3}{|c|}{ Migrant model } & \multicolumn{3}{|c|}{ Strictly resident model } \\
\hline & $\chi^{2}$ & DF & $\mathrm{p}$ & $\chi^{2}$ & DF & $p$ \\
\hline Natal colony & 7.46 & 4 & 0.11 & 57.03 & 4 & $<0.001$ \\
\hline Hatching date & 18.62 & 2 & $<0.001$ & 16.24 & 2 & $<0.001$ \\
\hline Interaction term & 5.92 & 8 & 0.66 & 7.15 & 8 & 0.52 \\
\hline
\end{tabular}

